\title{
CORRELATION OF VITAMIN D3 AND SERUM CALCIUM LEVEL WITH LEFT VENTRICULAR HYPERTROPHY PATIENTS.
}

1. MBBS, M.Phil

Assistant Professor Physiology People's University of Medical \& Health Sciences for Woman (SBA) 2. MD, FCPS

Associate Professor Medicine People's University of Medical \& Health Sciences for Woman (SBA)

3. MBBS, M.Phil

Chairman \& Associate Professor Physiology

People's University of Medical \& Health Sciences for Woman (SBA)

4. MBBS, DTCD, MD

Senior Registrar Medicine

People's University of Medical \&

Health Sciences for Woman (SBA)

5. MBBS, M.Phil

Lecturer of Physiology

People's University of Medical \&

Health Sciences for Woman (SBA).

6. MBBS, M.Phil

Assistant Professor Physiology

People's University of Medical \&

Health Sciences for Woman (SBA).

\section{Correspondence Address:}

Dr. Masood Nabi Noor

Senior lecturer of Physiology

People's University of Medical \&

Health Sciences for Woman (SBA).

mbox1260@gmail.com

Article received on:

09/05/2019

Accepted for publication:

14/10/2019

\begin{abstract}
Masood Nabi Noor ${ }^{1}$, Anawar Ali Jamali ${ }^{2}$, Hajra Naila Rahu ${ }^{3}$, Ghulam Mustafa Jamali ${ }^{4}$, Altaf Hussain Memon ${ }^{5}$, Ghulam Muhammad Phull ${ }^{6}$

ABSTRACT: Objectives: To assess the relation of LVH (left ventricular hypertrophy) due to essential hypertension with serum vitamin D3 and serum calcium levels. Study Design: Cross Sectional Research. Setting: Medicine/Cardiology department, Peoples Medical University Hospital, Nawabshah. Period: 1st January 2017 to 30th June 2017. Material \& Methods: To assess the correlation of 25-hydroxycholecalciferol and serum calcium with left ventricular hypertrophy in essential hypertension. The thickness of inter ventricular septum (IVS) and posterior wall (PWT) on echocardiography were used to categorize LVH into mild, moderate and severe. Results: Male predominated in the present study. Male to female ratio was 1.65:1. Male and female comprised $62.33 \%$ and $37.67 \%$ respectively. Chi square value ( $X^{2}$-value) was 14.7 with significant $p$-value. Mean + SD of 25-hydroxycholecalciferol in mild moderate and severe LVH were noted as $30+7.8,24.7+7.7$ and $14.9+6.1 \mathrm{ng} / \mathrm{dl}$ respectively. Mean $+\mathrm{SD}$ of serum calcium in mild moderate and severe LVH were noted as $9.20+0.51,8.93+0.72$ and $8.678+0.44 \mathrm{mg} / \mathrm{dl}$ respectively. Conclusion: In subjects with left ventricular hypertrophy in essential hypertension the serum levels of vitamin $D$ and calcium were low. There was a negative correlation with left ventricular hypertrophy and serum vitamin $D$ and serum calcium. Thus it could be concluded that in subjects with left ventricular hypertrophy the low levels of serum vitamin $\mathrm{D}$ could be an independent modifiable risk factor.
\end{abstract}

Key words: Hypertension, 25-Hydroxycholecalciferol, Left Ventricular Hypertrophy, Serum Calcium, Vitamin D3.

Article Citation: Noor MN, Jamali AA, Rahu HN, Jamali GM, Memon AH, Phull GM. Correlation of vitamin D3 and Serum Calcium level with Left Ventricular Hypertrophy patients. Professional Med J 2020; 27(6):1143-1150. DOI: 10.29309/TPMJ/2020.27.06.3697

\section{INTRODUCTION}

In the modern societies CVD (Cardiovascular disease) is becoming the most important reason for morbidity and mortality because of dietary factors and sedentary life style. Other factors also do play role ${ }^{1}$. Systemic hypertension is the first symptoms, the patients usually present in the clinical practice. Systemic hypertension increases the work load of left ventricle (LV). Remodeling followed by compensatory hypertrophy of LV is the earlier manifestation of essential systemic hypertension. LV disorders most often culminate in the cardiac related mortality. ${ }^{1}$ Low vitamin $D$ and serum calcium $(\mathrm{Ca}++)$ are nowadays prevalent in the country. A prevalence of $30-50 \%$ vitamin D and serum $\mathrm{Ca}++$ deficiency has been reported. In Pakistan, a prevalence as high as $90 \%$ vitamin D deficiency has been reported. ${ }^{2,3}$ Prevalence of vitamin D \& serum calcium deficiency is prevalent in South East Asian countries including the Pakistan. Population of Pakistan is at high risk due to increasing population, inflation, low dietary status and lacking health facilities. ${ }^{2}$ Recently relationship of decreased serum levels of vitamin D with left ventricular hypertrophy (LVH) has been reported and is a topic for debate and further research. ${ }^{4} \mathrm{LVH}$ is a maladaptive response of elevated after load in essential hypertension. Chronic persistent elevation of LV after load leads to $\mathrm{LVH}$, and carries risk of atrial fibrillation, diastolic dysfunction, heart failure and sudden cardiac death (SCD). LVH is a predictor and risk factor of cardiovascular disease events. ${ }^{5}$ Existing research suggests vitamin $\mathrm{D}$ and serum $\mathrm{Ca}++$ deficiency adversely affect the cardiovascular health. Growing body of research suggest role of 
vitamin $\mathrm{D}$ and serum $\mathrm{Ca}++$ deficiency might have deleterious implications for the cardiovascular health. Previous studies had reported vitamin D and serum calcium deficiency adversely affect cardiac contractility, vascular tone and cardiac tissue maturation. 6 ,7 Deficiency of both vitamin $\mathrm{D}$ and low serum $\mathrm{Ca}++$ very likely play an significant function in the pathogenesis of cardiac ailments. ${ }^{8}$ LVH and increased left ventricular mass (LVM) are risk factors of coronary artery disease (CAD), congestive cardiac failure(CCF) and brain stroke. $^{9}$

Interestingly, there is emerging evidence linking that, treatment with vitamin $D$ \& serum calcium supplementations improves survival of Hemodialysis patients through improved cardiac functions. ${ }^{10}$ It had been reported in double-blind, placebo-controlled randomized clinical trials that vitamin D \& serum calcium supplementations ameliorate the pro-inflammatory cytokine profile in patients with CCF. ${ }^{11}$ Link of vitamin $D$ \& serum calcium in our local population has not been assessed and never correlated with heart diseases. ${ }^{12}$ Decreased levels of serum vitamin D might have an essential responsibility in transforming cardio-vascular risk $^{5-7}$ predisposing to $\mathrm{LVH}^{8-10}$ and myocardial diseases. ${ }^{11,12}$ Essential hypertensive cohorts in prospective studies include however In subjects with cardiovascular hazard issues for instance obesity, age above 60 , diabetes mellitus were included in prospective cohorts of essential hypertension, all these risk factors are also negatively related by serum vitamin $\mathrm{D}$ and calcium deficiency status ${ }^{1,2}$ and might be the possible confounders. It is unclear that low levels of vitamin $D$ are the causative agent or it is the just an outcome for cardiovascular ailments. Keeping in view the published medical literature and vitamin $\mathrm{D}$ and serum $\mathrm{Ca}++$ deficiency as modifiable risk factors, it is worth to evaluate the link with left ventricular hypertrophy to prevent the cardiovascular associated mortality and morbidity simply through vitamin $\mathrm{D}$ and calcium supplementation.

Present research was aimed to analyze the serum levels of vitamin D (25-hydroxy cholecalciferol) and serum calcium in essential hypertension patients with evident of left ventricular hypertrophy in association with the electrocardiography and echocardiography. The present study hypothesized no co-relationship among vitamin $D$ and serum calcium with left ventricular hypertrophy in essential hypertension patients.

\section{MATERIAL \& METHODS}

This cross sectional research was carried out on 377 subjects in the Medicine/Cardiology department, Peoples Medical University Hospital, Nawabshah for the period of six months from (1st January 2017 to 30th June 2017). Those subjects whose age was from 35 to 65 years (both male and female) and diagnosed essential hypertension with evident of left ventricular hypertrophy were included in the study while those subjects who had secondary hypertension, valvular heart diseases, renal disease and pulmonary hypertension were excluded. The subjects suffering from essential hypertension with left ventricular hypertrophy were communicated for closeness. They were interviewed on general wellbeing for creating a friendly environment. The subjects were informed about the purpose of study. Subjects who showed willingness were asked to enter in the study protocol voluntarily. They were informed about the merits, demerits, gain and losses of study and were also informed that they can withdraw from study protocol at any time. A written signed consent was obtained from all volunteers. Confidentiality of patient data was maintained. Only authorized doctors could check the personal records of disease of patients.

The patients were diagnosed cases of essential hypertension with LVH examined by a consultant cardiologist. Patients were interviewed for collection of personal information for purpose of bio-data. Data was entered in a structured questionnaire Performa which was designed in English. Data was collected by researcher through face to face interview of study subjects. Written informed consent was essential for each of the willing volunteer subjects participating in the study protocol. Volunteers were asked for ECG records and blood sampling.

12 lead ECG was recorded by the researcher and 
findings were noted. ECG findings were discussed with consultant cardiologist. Patients were taken to echocardiography room for performing the procedure by a senior cardiologist. Findings were noted and discussed with cardiologist. Once essential hypertension was diagnosed of having $\mathrm{LVH}$, it qualified for the blood sampling.

Patients were approached for blood sampling. First ante-cubital fossa was checked for prominent vein for sampling purpose. The area was sterilized with alcohol swab. A $24 \mathrm{G}$ disposable syringe was used for venous blood sample collection. After an overnight fast of 8-12 hours and after all aseptic measures $3 \mathrm{ml}$ of venous blood was obtained in already sterile tubes and centrifuged for 05 minutes at $4000 \mathrm{rpm}$. Sera were separated. Sani-plast was applied after the procedure. Sera were aliquoted further in small volumes. Sera were stored at $-80^{\circ} \mathrm{C}$ until further use if delayed. Vitamin $D$ and serum calcium were estimated by standard methods.

VITAMIN D ESTIMATION vitamin d3 was estimated on ARCHITEC 11000 Dia Sys Merck system. Vitamin $D$ values were categorized.

Serum 25(OH) D concentrations $>30 \mathrm{ng} / \mathrm{ml}$ normal, $>20$ and $<30 \mathrm{ng} / \mathrm{ml}$ insufficiency and deficiency $<20 \mathrm{ng} / \mathrm{ml}^{13}$

Serum Calcium Estimation

Calcium was estimated by automated Roche clinical analyzers. Normal serum $\mathrm{Ca}++$ levels were taken as $9-10.5 \mathrm{mg} / \mathrm{dl}$ (2.2-2.6 $\mathrm{mmol} / \mathrm{L})$.

Lvh Criteria (Echocardiography)

Left ventricular hypertrophy (LVH) was categorized as normal $6-10 \mathrm{~mm}$ mild LVH 11-13, moderate LVH 14-16 $\mathrm{mm}$ and severe LVH >17 mm criteria;

Group data noted on Performa was typed on Microsoft Excel sheet. Research variables were also typed on SPSS 22.0. Data value of research variables were copied from Microsoft Excel sheet to SPSS sheet. Student's t-test was used to analyze the variable such as continuous/ numerical, mean \pm S.D and graphs were used to present the data. Chi square test was used for analysis of categorical variables. Outcomes of study were shown as frequency, \% and graphs. Data was analyzed at Confidential interval of (95\%) and $\mathrm{P}<0.05$ were used to analyze the data.

\section{RESULTS}

This current cross sectional research was performed to evaluate the correlation of 25-hydroxycholecalciferol and serum calcium with left ventricular hypertrophy in essential hypertension.

Table-I. Demography with age, gender, LVH, Vit D3 and calcium.

\section{Age distribution}

The average age of the research populace was noted as $54.11 \pm 6.85$ as shown in Table-I. Mean age shows, the study population was mostly elderly people which had been suffering from essential hypertension since long periods.

\section{Gender distribution}

Male predominated in the present study. Male to female ratio was $1.65: 1$. Male and female comprised $62.33 \%$ and $37.67 \%$ respectively.

Left Ventricular Hypertrophy (LVH)

Thickness of inter-ventricular septum (IVS) and posterior wall (PWT) on echocardiography were considered to categorize LVH (Left ventricular hypertrophy) into mild, moderate and severe. Frequency of LVH as mild, moderate and severe was noted in 15.64\%, 39.25\% and $45.09 \%$ respectively as shown in Table-I.

25-hydroxycholecalciferol (25-OH-D $)$ (ng/dl) Mean \pm SD of 25-hydroxycholecalciferol $(25-\mathrm{OH}$ $\mathrm{D}_{3}$ ) of total study subjects was noted as $21.27 \pm$ $9.29 \mathrm{ng} / \mathrm{dl}$. Frequency of 25 -hydroxycholecalciferol $\left(25-\mathrm{OH}-\mathrm{D}_{3}\right)$ as normal, insufficiency and deficiency were noted in $18.30 \%, 29.70 \%$ and $51.98 \%$ respectively as shown in Table-l.

Mean \pm SD of serum calcium (S. $\mathrm{Ca}++$ ) of total study subjects was noted as $8.87 \pm 0.61 \mathrm{mg} /$ dl Frequency of serum calcium (S. $\mathrm{Ca}++$ ) as normal and deficiency was noted in $29.70 \%$ and $70.29 \%$ of subjects respectively. 
Frequency of normal, insufficient and difficiency of 25-hydroxycholecalciferol (25-OH- $\left.\mathrm{D}_{3}\right)$ according to LVH size mild, moderate and severe is shown in Table-II. Majority of subjects with severe LVH showed 25-hydroxycholecalciferol $\left(25-\mathrm{OH}-\mathrm{D}_{3}\right)$ deficiency. The differences were found statistically significant $\left(X^{2}=14.07, p=0.0001\right)$.

On other hand serum calcium and LVH size mild, moderate and severe majority of subjects with severe LVH showed serum calcium low levels. The differences were found statistically significant $\left(X^{2}=14.07, p=0.0001\right)$. Shown in Table-II

Pearson's correlation of LVH with 25-OH-D and S. Ca+ + is shown in Table-III. LVH showed negative correlation with $25-\mathrm{OH}-\mathrm{D}_{3}$ and $\mathrm{S}$. $\mathrm{Ca}++$ as indicated by correlation coefficient (r-value) and p-value. 25-OH-D $\mathrm{D}_{3}$ and $\mathrm{S}$. $\mathrm{Ca}++$ showed r-value of -0.475 and -0.242 respectively $(p=$ 0.0001 ) as shown in Table-III.

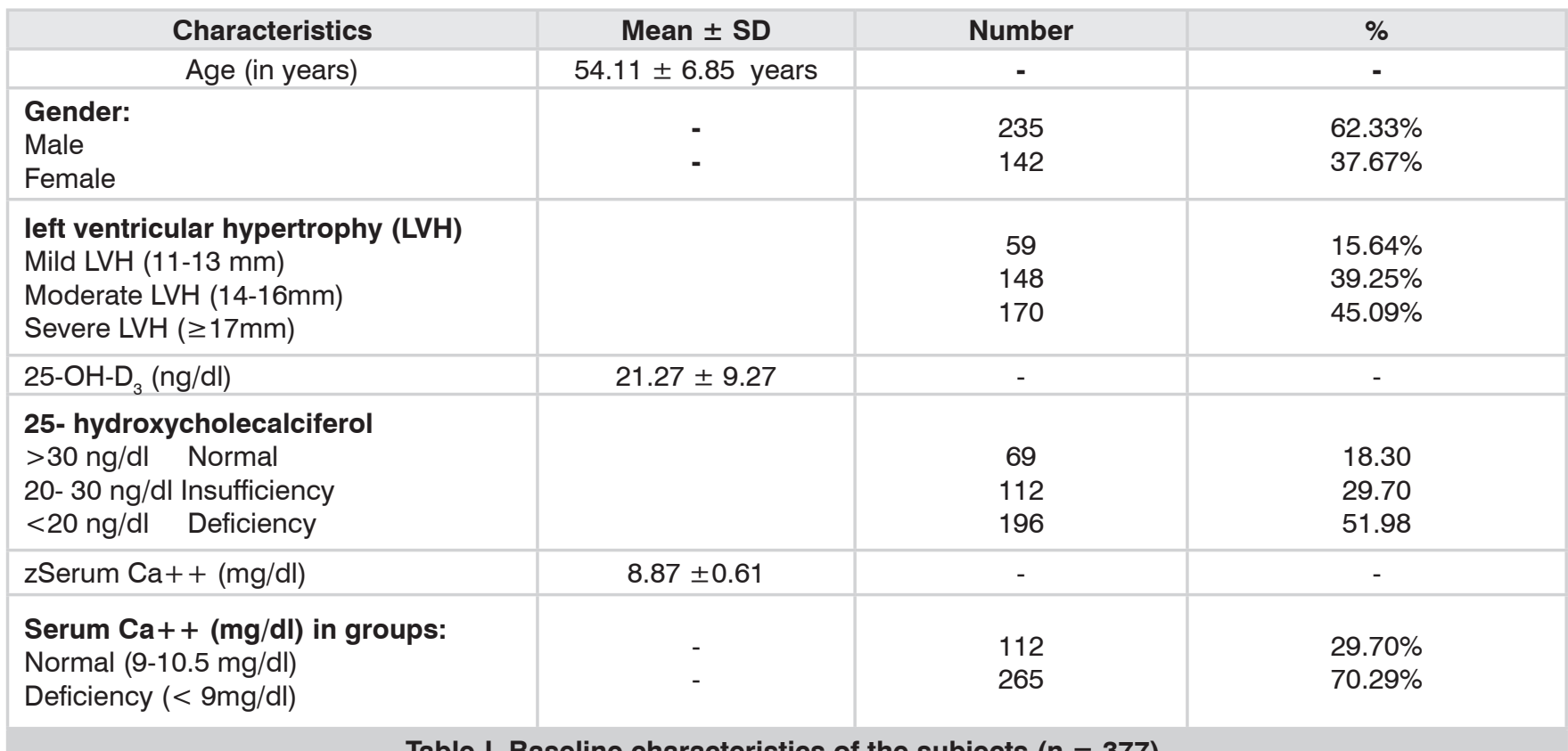

Table-I. Baseline characteristics of the subjects $(n=377)$.

\begin{tabular}{|c|c|c|c|c|c|}
\hline 25-OH-D 3 & $\begin{array}{c}\text { Mild LVH } \\
n=170\end{array}$ & $\begin{array}{c}\text { Moderate LVH } \\
n=148\end{array}$ & $\begin{array}{l}\text { Severe LVH } \\
n=170\end{array}$ & $\mathrm{X}^{2}$-Value & P-Value \\
\hline $\begin{array}{l}>30 \mathrm{ng} / \mathrm{dl} \quad \text { Normal } \\
20-30 \mathrm{ng} / \mathrm{dl} \text { Insufficiency } \\
<20 \mathrm{ng} / \mathrm{dl} \quad \text { Deficiency }\end{array}$ & $\begin{array}{c}31 \\
31 \\
7\end{array}$ & $\begin{array}{c}28 \\
76 \\
8\end{array}$ & $\begin{array}{c}0 \\
41 \\
155\end{array}$ & 14.07 & 0.0001 \\
\hline $\begin{array}{l}\text { Serum Ca }++ \\
\text { Normal }(9-10.5 \mathrm{mg} / \mathrm{dl}) \\
\text { Deficiency }(<9 \mathrm{mg} / \mathrm{dl})\end{array}$ & $\begin{array}{c}51 \\
8\end{array}$ & $\begin{array}{l}67 \\
81\end{array}$ & $\begin{array}{l}73 \\
97\end{array}$ & 14.07 & 0.0001 \\
\hline
\end{tabular}

Table-II. 25- hydroxycholecalciferol with left ventricular hypertrophy (LVH) ( $\mathbf{n}=377)$.
Scatter Figure-1,2 and 3 show the correlation of $25-\mathrm{OH}-\mathrm{D}_{3}$ and $\mathrm{S}$. Ca++ with $\mathrm{LVH}$ respectively. Decline of interpolation line indicates negative correlation co-efficient.

Figure-1. Pearson's correlation of LVH and 25-hydroxycholecalciferol (Scatter plot). It shows negative correlation as indicated by correlation co-efficient $(r=-0.475)(p=0.0001)$.

Figure-2. Pearson's correlation of left ventricular hypertrophy and serum calcium (Scatter plot). It shows negative correlation as indicated by

Figure-3. Pearson's correlation of 25-hydroxycholecalciferol and serum calcium (Scatter plot). It shows positive correlation as indicated by correlation co-efficient $(r=0.711)$ $(p=0.0001)$. correlation co-efficient $(r=-0.242)(p=0.0001)$. 


\begin{tabular}{|c|c|c|c|}
\hline & & 25-OH-D3 (ng/dl) & Serum Ca $++(\mathbf{m g} / \mathrm{dl})$ \\
\hline \multirow[b]{2}{*}{$\mathrm{LVH}(\mathrm{mm})$} & $r$ - value & $-0.475^{\star \star}$ & $-0.242^{\star *}$ \\
\hline & P-value & 0.0001 & 0.0001 \\
\hline \multicolumn{4}{|c|}{ **. Significant Correlation at the level 0.01 (2-tailed) } \\
\hline
\end{tabular}

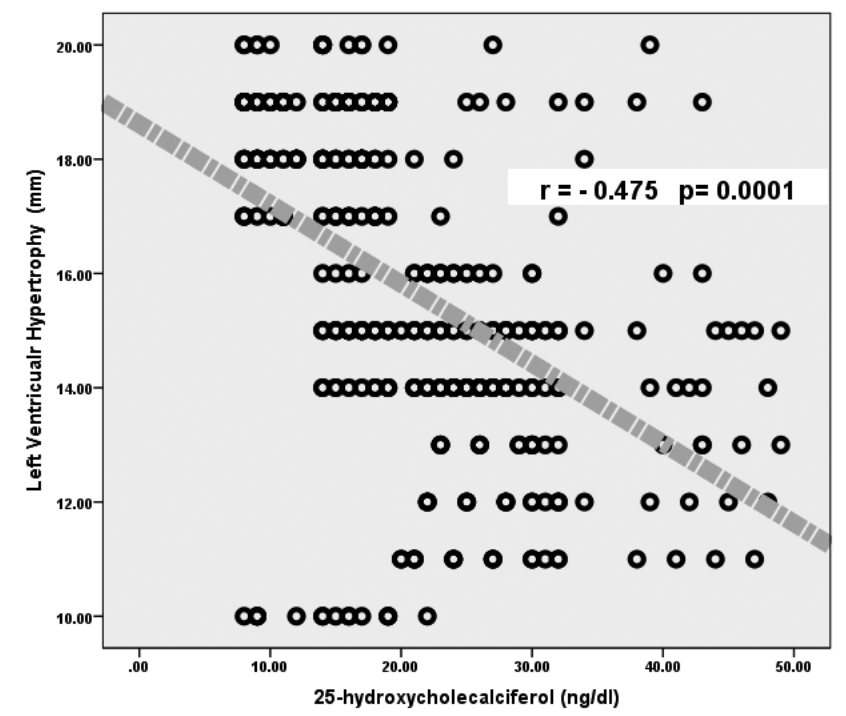

Figure-1. Pearson's correlation of LVH and 25-hydroxycholecalciferol (Scatter plot). It shows negative correlation as indicated by correlation coefficient $(r=-0.475)(p=0.0001)$.

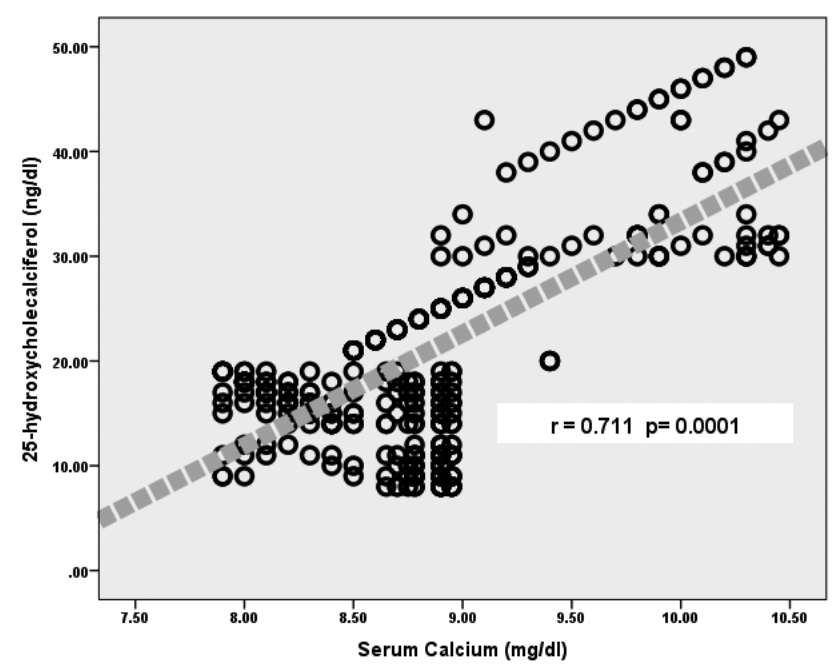

Figure-3. Pearson's correlation of 25-hydroxycholecalciferol and serum calcium (Scatter plot). It shows positive correlation as indicated by correlation co-efficient $(r=0.711)(p=0.0001)$.

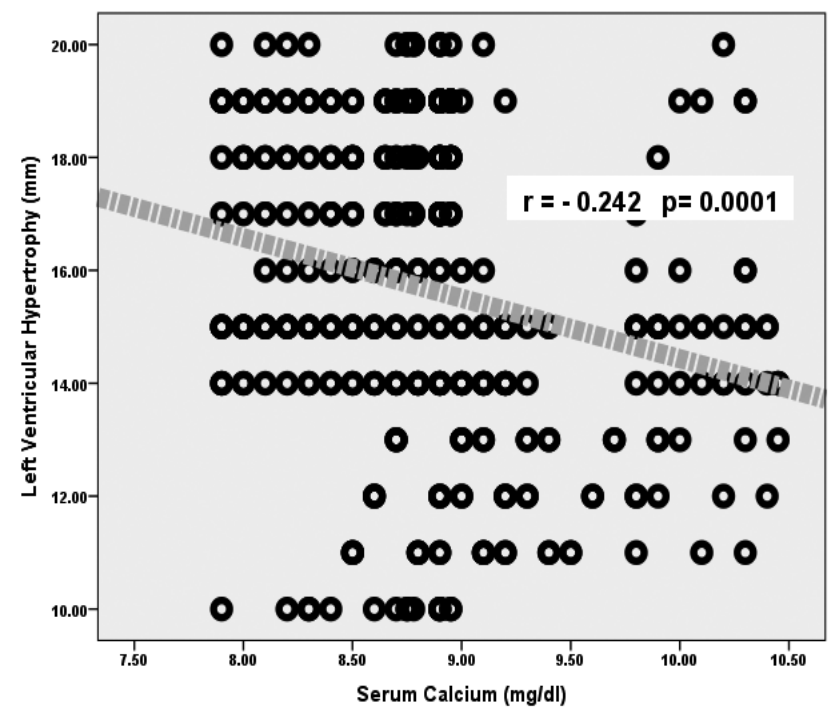

Figure-2. Pearson's correlation of left ventricular hypertrophy and serum calcium (Scatter plot). It shows negative correlation as indicated by correlation coefficient $(r=-0.242)(p=0.0001)$.

\section{DISCUSSION}

The present study is the first research being reporting on the relationship of serum vitamin $\mathrm{D}_{3}$ and serum calcium with left ventricular hypertrophy (LVH) in essential hypertension. It was hypothesized that there is no relationship $\left(\mathrm{H}_{0}\right)$ between the vitamin D3, serum $\mathrm{Ca}++$ and $\mathrm{LVH}$. But the present study found a significant correlation of occurrence of vitamin $\mathrm{D}_{3}$ and serum calcium deficiency in LVH subjects. The present study reports a significant deficiency of vitamin $D_{3}$ and serum calcium in our study population. A previous study reported that the essential hypertension causes hypernatremia which facilitates calciuresis. Low serum calcium stimulates PTH secretion. PTH leads to increased protein synthesis and ultimately results in myocardial hypertrophy and $\mathrm{LVH}^{14}{ }^{14}$ In present study serum vitamin $D_{3}$ and serum calcium were found low in LVH subjects and were negatively correlated with it. Deficiency of vitamin $D_{3}$ were 
noted in $18.30 \%, 29.70 \%$ and $51.98 \%$ respectively.

The role of vitamin D and NT-pro BNP levels in thalassemic children and their correlation with LV functions were reported by Ambarwati et al ${ }^{15}$ from Indonesia. The study reported significant negative correlation among serum levels vitamin $D$ and LVEF (left ventricular ejection fraction) similar outcomes were also noted in the present study. Although the study population is different but the findings of Ambarwati et al are in keeping with the present study. Helvaci et $\mathrm{al}^{16}$ reported findings of the correlations between serum levels of calcium and left ventricular mass index (LVMI) in essential hypertension. They conducted a cross sectional study similar to present study. A significant correlation among vitamin $\mathrm{D}$, calcium, PTH, calcitonin and LVMI were reported. Low serum calcium and Vitamin D of Hevlaciet al are parallel to our present study; however, the PTH and Calcitonin are not comparable. Hevlaci et al reported the of $\mathrm{LVH}$ was caused by elevated $\mathrm{PTH}$, which in turn provokes the myocardial hypertrophy and consequent upon the LVH. A recent study by Nitta et al $^{17}$ reported serum calcium in normal, LVH and vitamin D supplemented subjects as $9.01 \pm 0.55,8.87 \pm 0.67$ and $9.05 \pm 0.51 \mathrm{mg} /$ dl respectively. ${ }^{17}$ In present study LVH subjects showed low serum calcium of $8.87 \pm 0.61 \mathrm{mg} / \mathrm{dl}$ $(d f=376$, t-value 279.14, $p=0.0001)$. Our finding of low serum $\mathrm{Ca}++$ in $\mathrm{LVH}$ is consistent with Nitta et al. ${ }^{17}$ Pandet et al concluded that despite growing consensus on deficiency of vitamin D and cardiac disease, the relationship was not found in their study. No significant association of serum levels of vitamin $D$, atrial volume index $(\mathrm{AVI}), \mathrm{LVH}$ and LV diastolic function.

A recent study by $L i$ et al $^{19}$ reported high serum $\mathrm{Ca}++$ in $\mathrm{LVH}$. The findings are in controversyl to present study. Most probable reason for such controversial result may be researcher bias; otherwise it is contrary to the fact. Whitham et $\mathrm{al}^{20}$ reported a study from Heart Research Center, UK. They administered high-dose intermittent oral vitamin D3 therapy but reported no effect on systemic hypertension and LVH in patients with resistant hypertension. The findings are in contrast to present study. Witte et $\mathrm{al}^{21}$ enrolled
229 of cardiac failure having deficiency of vitamin D i.e. $<20 \mathrm{ng} / \mathrm{ml}$. The subjects were given supplements of vitamin $D_{3}$ for one year at dose of 4,000 IU/day. After one year, 6-min walk distance and LV ejection fraction were not improved. They concluded that the vitamin D supplementations did not improve myocardial contractility. The reason could be small sample size, different patient cohort (resistant hypertension and cardiac failure by Whitam ${ }^{20}$ and Witte, ${ }^{21}$ genetic variations, geographical and environmental factors. Thadani et $\mathrm{al}^{22}$ reportedthat the vitamin $\mathrm{D}$ receptor activation produced $\mathrm{LVH}$ regression and prevented againstit in patients of chronic kidney disease (CKD). It was concluded that the vitamin $\mathrm{D}$ supplements maybe presecribed to $\mathrm{LVH}$ patients in CKD. Rainaet $\mathrm{al}^{23}$ from India has recently reported that the correlation exists between vitamin $\mathrm{D}$ deficiency and chronic stable angina. They concluded that the low levels of vitamin $D$ might be an independent modifiable risk factor for CAD. A study reported from India by Roy et $\mathrm{al}^{24}$ showed that deficiency of vitamin D was extremely predominant between subjects of acute myocardial infarction (AMI). Vitamin D levels were significantly low in subjects who were suffering from pulmonary disease like pulmonary tuberculosis, Parkinson's disease and infertility also. ${ }^{25,26,27}$ The findings of present study are also matchable with many different other studies carried at local levels to check the relationship of vitamin $\mathrm{d}$ and different diseases were significant. The findings of present study are also matchable with many different other studies carried at local levels to check the relationship of vitamin $d$ and different diseases were significant.

\section{CONCLUSION}

The serum levels of vitamin D and calcium were low in subjects with left ventricular hypertrophy in subjects with essential hypertension. Serum levels of vitamin $\mathrm{D}$ and calcium showed a negative correlation with left ventricular hypertrophy. Thus, it may be concluded that the low vitamin $D$ and serum calcium level may be an independent modifiable risk factor for left ventricular hypertrophy.

\section{RECOMMANDATIONS}


Vitamin D supplements and calcium supplements may be prescribed by treating physicians. However, further large scale studies are recommended to be conducted throughout country to authenticate the vitamin $D$ and serum calcium levels for left ventricular hypertrophy at national levels. Vitamin $D$ and serum calcium deficiency, being a modifiable risk factor may prove helpful in reducing mortality and morbidity by supplementations.

\section{Copyright@ 14 Oct, 2019.}

\section{REFERENCES}

1. Pilz S, Verheyen N, Grübler MR, Tomaschitz A, März W. Vitamin D and cardiovascular disease prevention. Nat Rev Cardiol. 2016; 13(7):404-17.

2. Masood SH IM. Prevalence of vitamin D deficiency in South Asia. Pak J Med Sci. 2008; 24(6):891-7.

3. Pilz S, Gaksch M, O'Hartaigh B, Tomaschitz A, März W. The role of vitamin $D$ deficiency in cardiovascular disease: Where do we stand in 2013? Arch Toxicol. 2013; 87(12):2083-103.

4. Carvalho LSF, Sposito AC. Vitamin D for the prevention of cardiovascular disease: Are we ready for that? Atherosclerosis. 2015; 241(2):729-40.

5. Levy D, Garrison RJ, Savage DD, Kannel WB, Castelli WP. Prognostic implications of echocardiographically determined left ventricular mass in the framingham heart study. N Engl J Med. 1990; 322(22):1561-6.

6. Camici M, Galetta F, Franzoni F, Carpi A, Zangeneh F. Vitamin D and heart. Intern Emerg Med. 2013;8(S1):59.

7. Walker MD, Fleischer J, Rundek T, McMahon DJ, Homma $\mathrm{S}$, Sacco R, et al. Carotid vascular abnormalities in primary hyperparathyroidism. J Clin Endocrinol Metab. 2009; 94(10):3849-56.

8. Vasan RS, Larson MG, Levy D, Evans JC, Benjamin EJ. Distribution and categorization of echocardiographic measurements in relation to reference limits: The framingham heart study: Formulation of a heightand sex-specific classification and its prospective validation. Circulation. 1997; 96(6):1863-73.

9. Gardin JM, McClelland R, Kitzman D, Lima JA, Bommer W, Klopfenstein HS, et al. M-mode echocardiographic predictors of six- to seven-year incidence of coronary heart disease, stroke, congestive heart failure, and mortality in an elderly cohort (the Cardiovascular Health Study). Am J Cardiol. 2001;87(9):1051-7.
10. Schleithoff SS, Zittermann A, Tenderich G, Berthold HK, Stehle P, Koerfer R. Vitamin D supplementation improves cytokine profiles in patients with congestive heart failure: a double-blind, randomized, placebocontrolled trial. The American journal of clinical nutrition. 2006 Apr;83(4):754-9.

11. Frohlich ED, Apstein C, Chobanian A V, Devereux RB, Dustan HP, Dzau V, et al. The Heart in hypertension. N Engl J Med. 1992;327(14):998-1008.

12. Khan $A H$, Majid $H$, lqbal $R$. Shifting of vitamin D deficiency to hypervitaminosis and toxicity. J Coll Physicians Surg Pak. 2014;24(7):536.

13. Shen L, Ji HF. Associations between vitamin D status, supplementation, outdoor work and risk of Parkinson's disease: a meta-analysis assessment. Nutrients. 2015 Jun;7(6):4817-27. https://doi. org/10.3390/nu7064817.

14. Gupta DK, Wang TJ. Looking for a brighter future in heart failure. J Am Coll Cardiol. 2016; 67(22):2604-6.

15. Ambarwati L, Rahayuningsih S, Setiabudiawan B. Association between vitamin $D$ levels and left ventricular function and NT-pro BNP levels among thalassemia major children with iron overload. Ann Pediatr Cardiol. 2016; 9(2):126 131.

16. Helvaci A, Copur B, Adas M. Correlation between left ventricular mass index and calcium metabolism in patients with essential hypertension. Balkan Med J. 2013; 30(1):85-9.

17. Nitta K, limuro S, Imai E, Matsuo S, Makino H, Akizawa T, et al. Retracted Article: Risk factors for increased left ventricular hypertrophy in patients with chronic kidney disease. Clin Exp Nephrol. 2013;17(5):730-42.

18. Pandit A, Mookadam F, Boddu S, Aryal Pandit A, Tandar A, Chaliki $H$, et al. Vitamin D levels and left ventricular diastolic function. Open Hear. 2014 Feb 17; 1(1):e000011.

19. Li J, Wu N, Li Y, Ye K, He M, Hu R. Cross-sectional analysis of serum calcium levels for associations with left ventricular hypertrophy in normocalcemia individuals with type 2 diabetes. Cardiovasc Diabetol. 2015;14(1):43.

20. Witham MD, Ireland S, Houston JG, Gandy SJ, Waugh $S$, MacDonald TM, et al. Vitamin D therapy to reduce blood pressure and left ventricular hypertrophy in resistant hypertension. Hypertension. 2014; 63(4):706-12. 
21. Witte KK, Byrom R, Gierula J, Paton MF, Jamil HA, Lowry JE, et al. Effects of Vitamin D on cardiac function in patients with chronic HF. J Am Coll Cardiol. 2016; 67(22):2593-603.

22. Thadhani R, Appelbaum E, Chang Y, Pritchett Y, Bhan I, Agarwal $R$, et al. Vitamin $D$ receptor activation and left ventricular hypertrophy in advanced kidney disease. Am J Nephrol. 2011; 33(2):139-49.

23. Raina AH, Allai M, Shah Z, Changal K, Raina M, Bhat F. Association of low levels of vitamin $D$ with chronic stable angina: A prospective case-control study. $\mathrm{N}$ Am J Med Sci. 2016; 8(3):143 150.

24. Roy A, Lakshmy R, Tarik M, Tandon N, Reddy KS, Prabhakaran D. Independent association of severe vitamin $D$ deficiency as a risk of acute myocardial infarction in Indians. Indian Heart J. 2015; 67(1):2732.
25. Jamali AA, Jamali GM, Tanwani BM, Jamali NH, Bhatia MR. Frequency of Low Vitamin D3 Levels in Subjects with Parkinson's disease. A Study Conducted at $\mathrm{PMCH}$, a Tertiary Care Hospital, Nawabshah. Advances in Parkinson's disease.Vol.7 No.1 PP. 7-18. Pub. Date: February 26, 2018. DOI: 10.4236/apd.2018.71002

26. Jamali $A A$, Tanwani BM, Jamali GM, Jamali $A A$, Suhail MA, Kumar J, Kumar R. Vitamin D3: Association of low Vitamin D3 levels with semen abnormalities in infertile males. Advances in Sexual Medicine. Vol.8 No.4 PP. 39-59. Pub. Date: August 27, 2018. DOI: 10.4236/asm.2018.84004.

27. Jamali $A A$, Lighari JH, Shaikh $S$, Jamali GM, Tanwani BM, Channa MA, Jamali AA, Suhail MA. Vitamin D: Level of Vitamin D3 in AFB Positive PTB patients in initial diagnostic phase. Journal of Tuberculosis Research. Vol.6 No.4 PP. 251-269. Pub. Date: October 12, 2018 DOI: 10.4236/jtr.2018.64023.

\begin{tabular}{|c|c|c|c|}
\hline \multicolumn{4}{|c|}{ AUTHORSHIP AND CONTRIBUTION DECLARATION } \\
\hline Sr. \# & Author(s) Full Name & Contribution to the paper & Author(s) Signature \\
\hline 1 & Masood Nabi Noor & Design + Introduction & \\
\hline 2 & Anawar Ali Jamali & Material and methods. & $\operatorname{ton} x=5 \mathrm{C}$ \\
\hline 3 & Hajra Naila Rahu & Data entry & H8 \\
\hline 4 & Ghulam Mustafa Jamali & Data analysis & \\
\hline 5 & Altaf Hussain Memon & Resutls. & \\
\hline 6 & Ghulam M. Phull & Discussion & \\
\hline
\end{tabular}

